\title{
Does aquatic sediment pollution result in contaminated food sources?
}

\author{
Josef Václavík, Pavla Sehonová, Zdeňka Svobodová \\ University of Veterinary Sciences Brno, Faculty of Veterinary Hygiene and Ecology, \\ Department of Animal Protection and Welfare \& Veterinary Public Health, Brno, Czech Republic
}

Received June 29, 2021

Accepted November 9, 2021

\begin{abstract}
The sediment pollution of the aquatic environment by waste due to anthropogenic activity is of an increasing concern. The contaminants coming from the aquatic environment can enter the aquatic food chain and accumulate in the tissues of fish and shellfish used for human consumption. The aim of this study was to sum up the current level of knowledge concerning the pollution of aquatic sediments and its transfer to aquatic foods as well as to indicate whether such contamination has the potential to affect the health and welfare of aquatic organisms as well as the quality and safety of the species intended for human consumption. Based on the results of scientific studies, the European Food Safety Authority, and the Rapid Alert System for Food and Feed, contamination of fish and seafood occurs predominantly through their diet and the levels of bioaccumulative contaminants are higher in fish which rank higher in the food chain. Contamination of aquatic habitats can not only significantly affect behavior, development, and welfare of aquatic organisms, but it can also affect the safety of fish and seafood for human consumption.
\end{abstract}

Heavy metals, pharmaceuticals, pesticides, nanoparticles, microplastics, RASFF

The sediment pollution of the aquatic environment by waste due to anthropogenic activity is of an increasing concern. Since the world's population is on a growing trend, the demand for natural resources and their consumption as well as generation of waste are increasing. The waste then reaches the aquatic environment (Haseena et al. 2017) and can become persistent with its increasing concentration there (Ejaz et al. 2010; Skenderovic et al. 2015).

The most common routes of entry for the pollutants into the aquatic environment are through wastewater treatment plants, landfill discharges, mining companies, pharmaceutical and agronomic industries, as well as natural processes such as volcanic activity, weathering and soil erosion and flooding (Owa 2013; Dvidedi 2017; Haseena et al. 2017; Briffa et al. 2020).

Contaminants released in open waters are generally trapped by suspended mineral and organic particles in the aquatic environment and concentrated in surrounding sediments, which can pose a serious threat to aquatic life ( $\mathrm{Zhu}$ et al. 2019). Various studies show the long-term toxic effects of different groups of pollutants (pesticides, heavy metals, medicaments, etc.) on organisms ranging from invertebrates to fish and aquatic mammals. In particular, behavioural changes, immunodeficiency or side effects on the reproduction and endocrine systems, and many others have been described (Hontela et al. 1996; Huang et al. 2010; Vaclavik et. al 2020).

Moreover, contaminants from the aquatic environment can enter the aquatic food chain and concentrate in the tissues of fish and shellfish used for human consumption. Fish are contaminated predominantly through their diet, and levels of bioaccumulative contaminants are higher in fish which rank higher in the food chain (EFSA 2005).

Therefore, this review aimed to sum up the current level of knowledge concerning the pollution of aquatic sediments and their transfer to the aquatic food chain. Moreover,

Address for correspondence:

Pavla Sehonová

Faculty of Veterinary Hygiene and Ecology

University of Veterinary Sciences, Brno, Czech Republic

Palackého tř. 1946/1, 61242 Brno, Czech Republic 
based on the results of such review, the aim of this study was also to assess whether such contamination has the potential to affect the health and welfare of aquatic organisms as well as the quality and safety of the species intended for human consumption.

\section{Heavy metals and intensive mining}

Although heavy metals are a natural part of the Earth's crust and their increased concentrations are found in volcanically active areas or localities where excessive erosion and soil weathering occur, at the same time they enter the environment, including water reservoirs, as a result of anthropogenic activity (Briffa et al. 2020). These elements are taken up by marine organisms and accumulated in organisms such as predatory fish which are higher up the food chain. As a result, the concentrations of many elements, including arsenic (As), cadmium $(\mathrm{Cd})$, lead $(\mathrm{Pb})$, and mercury $(\mathrm{Hg})$ can be relatively high in fish meat compared to other foods (EFSA 2005).

An example of a major source source if pollution of the aquatic ecosystem is intensive mining, which can use $\mathrm{Hg}$ in the gold extraction process. This results in $\mathrm{Hg}$ deposits in surrounding waters reservoirs, including the sediment. A study from Senegal (Niane et al. 2019) described an increased $\mathrm{Hg}$ content in the sediment (up to $1.16 \mathrm{mg} / \mathrm{kg}$ ) on the Gambia River in intensive mining areas. Similar studies from other parts of the world (Shi et al. 2019; Beck et al. 2020) describe the impact of the mining process on the environment. Since $\mathrm{Hg}$ is one of the most widespread contaminants in aquatic ecosystems, the Minamata Convention on mercury was signed by more than 120 countries and came into force in 2017 in order to prevent the risks connected to environmental mercury exposure. As a result, the manufacture, import and export of mercury-added products, with certain exceptions, has no longer been allowed since 2020 (Regulation (EU) 2017/852).

Wei et al. (2019) analyzed sediments of the Raohe Basin in China, where the mean concentrations of $\mathrm{Cd}, \mathrm{Pb}$, and $\mathrm{As}$ were $0.51 \mathrm{mg} / \mathrm{kg}, 39.63 \mathrm{mg} / \mathrm{kg}$, and $35.26 \mathrm{mg} / \mathrm{kg}$, respectively. During sedimentation, heavy metals may react with other elements and form more toxic products. An example is the formation of methyl mercury resulting from the reaction of inorganic $\mathrm{Hg}$ with sulphate and iron-reducing bacteria (Zeng et al. 2016). After sedimentation, heavy metals enter aquatic organisms from benthos to vertebrates, including fish with the highest load of risk to organisms at the top of the food chain, especially predatory fish (Buck et al. 2019).

Many studies described the presence of metals in organisms of different trophic levels. Azizi et al. (2018) measured the occurrence of heavy metals in sea mussels during the year with the highest values for Cd up to $3.3 \mathrm{mg} / \mathrm{kg}$ in the winter season. Abd-Elghany et al. (2020) detected $0.39 \mathrm{mg} / \mathrm{kg}$ of As and $0.24 \mathrm{mg} / \mathrm{kg}$ of Cd in shrimp samples in Egypt. Usman et al. (2021) found an As concentration of $5.04 \mathrm{mg} / \mathrm{kg}, 5.79 \mathrm{mg} / \mathrm{kg}$, and $2.13 \mathrm{mg} / \mathrm{kg}$ in the meat, gills, and liver of commercial fish, respectively. Costa et al. (2020) determined the concentration of metals in fish meat near the Portugal coast with the highest level of $0.20 \mathrm{mg} / \mathrm{kg}$ of mercury in adults. Dabeka et al. (2011) determined the concentration of mercury in predatory fish purchased in Canada which ranged up to $2.34 \mathrm{mg} / \mathrm{kg}$. Nicklisch et al. (2017) detected $\mathrm{Hg}$ in caught yellowfin tuna in the range of 0.03 to $0.82 \mathrm{mg} / \mathrm{kg}$.

Long-time exposure of aquatic organisms to these substances could have deleterious effects on their health, which can be manifested by various symptoms. Ungherese et al. (2010) described the negative correlation between the heavy metal pollution and genetic diversity in Mediterranean populations of the sandhopper (Talitrus saltator). A negative impact on different organ systems (mainly the digestive tract) of the freshwater crayfish (Astacus astacus) was evaluated by Meyer et al. (1991). For fish, most metals target the haematopoietic system, central nervous system, liver, kidneys, and reproductive tract (Burger 2008; Castro-Gonzalez and Mendez-Armenta 2008; Xie et al. 2020). 
Mercury poisoning in individual adult fish is not clinically noticeable. The most frequent sign is reproductive problems manifested by disorders of gametogenesis and the saline viability of fish embryos, including malformations (Huang et al. 2010; Xie et al. 2020). Damage to parenchymal organs can be proven by pathological examination.

The organ most susceptible to cadmium are the kidneys, which are at risk of chronic failure. Cadmium in fish also negatively affects the liver function, central nervous system, endocrine system, embryo-larvae development, and causes developmental deformities with potential teratogenicity and mutagenicity (Hontela et al. 1996; Serafim and Bebianno 2007; Burger 2008).

Lead has a high affinity for enzymes involved in heme synthesis, resulting in anaemic states at the final stage. A negative feature of lead is the ability to squeeze calcium from bones and deposit there instead. Lead poisoning in fish is most often manifested by damage to the skin epithelium; with prolonged exposure, haematopoietic and CNS damage occurs (Rogers et al. 2003; Castro-Gonzalez and Mendez-Armenta 2008).

Arsenic is a highly toxic metal that occurs in nature mainly in the form of sulphides. In water, As is most often found in the inorganic form either in a 5-valent or 3-valent oxidation stage. Prolonged exposure to arsenic can result in weight loss, skin problems such as hyperkeratosis, liver necrosis, CNS and haematopoietic disorders (Sorensen et al. 1985; Castro-Gonzalez and Mendez-Armenta 2008).

In terms of human safety, the maximum limits for selected metals in fish and other aquatic organisms intended for human consumption are given in the Commission Regulation No. 1881/2006 setting maximum concentrations for certain contaminants in foodstuffs (Commission Regulation 2006) as follows: $0.3,0.5,1$, and $1.5 \mathrm{mg} / \mathrm{kg}$ (based on the species) for lead; $0.05,0.1,0.3$, and 0.5 and $1 \mathrm{mg} / \mathrm{kg}$ (based on the species) for cadmium; 0.5 and $1 \mathrm{mg} / \mathrm{kg}$ for mercury.

Mercury exposure can cause major damage to the CNS, skin, and kidneys, as well as to the foetus. The classic case described is the so-called Minamata Disease, which took place in the 1950s in the Minamata fishing bay in Japan (Reis and Mizusawa 2019). The impact of lead poisoning is manifested by disorders of the digestive tract, CNS, and the haematopoietic system, by kidney damage, and by muscle and bone growth retardation (Bischoff et al. 2010). Moreover, based on the data from the Rapid Alert System for Food and Feed (RASFF 2021), the limit content of heavy metals in fish and seafood is still a valid problem for products coming from both European Union as well as third world countries. For these reasons, it is important to monitor and regulate the concentration of heavy metals in the water ecosystem and human food.

\section{Pesticides}

A dangerous feature of pesticides is the ability to persist and bioaccumulate in water, sediments, and organisms while negatively impacting them. There is a large chemical spectrum of pesticides such as organochlorinated pesticides (some of the first pesticides used) that belong to the group of persistent organic pollutants (POPs) (Martyniuk et al. 2020; Yang et al. 2020), organophosphates, carbamates, pyrethroids, triazine, chloroacetanilide, and others, which persist in the aquatic ecosystem (Buah-Kwofie and Humphries 2021; Mwevura et al. 2021).

A number of studies have described various pesticides occurring in surface waters, water sediment, and animals, at concentrations ranging from $\mathrm{ng} / \mathrm{kg}$ to $\mathrm{mg} / \mathrm{kg}$ (Arisekar et al. 2019; Buah-Kwofie and Humphries 2021; Mwevura et al. 2021). For example, in Tanzania, 21 types of residues of different pesticides were found in the soil, water, and sediment of the Rufiji River Delta (Mwevura et al. 2021). The samples taken in the study included residues of organochlorinated pesticides such as heptachlor $(0.5 \mu \mathrm{g} / \mathrm{kg})$ 
or cyklodien $(85 \mathrm{ng} / \mathrm{l})$, and carbamate thiobencarb $(3.3 \mu \mathrm{g} / \mathrm{kg})$. Buah-Kwofie and Humphries (2021) described the occurrence of organochlorinated pesticides (heptachlor, dieldrin) in fish and catchment sediments of the African lake St. Lucia at a concentration ranging 74-510 $\mu \mathrm{g} / \mathrm{kg}$ for sediment from the affluent river and $450 \mu \mathrm{g} / \mathrm{kg}$ for muscle tissue of adult fish (Oreochromis mossambicus) caught from the lake. The sediment samples on river drainage from Indian tea plantations showed a pyrethroid pollution by cypermethrin at a concentration of up to $0.08 \mu \mathrm{g} / \mathrm{kg}$ (Arisekar et al. 2019).

$\mathrm{Li}$ et al. (2021) measured residues of organochlorine pesticides in organisms from the East Sea area of the Shandong Peninsula, the Yellow Sea, China, from caught samples including fish (Platycephalus indicus, Liparis tanakae, Chaeturichthys stigmatias), a crustacean (Oratosquilla oratoria), and mollusks (Mytilus galloprovincialis, Ruditapes philippinarum) at a hexachlorhexan concentration of up to $0.457 \mathrm{mg} / \mathrm{kg}, 0.165 \mathrm{mg} / \mathrm{kg}$, and 0.657 for fish, crustacean and mollusk, respectively. Arisekar et al. (2019) detected residues of cypermethrin up to $26.17 \mu \mathrm{g} / \mathrm{kg}$ in meat tissue from fish caught in India. Wild marine benthic fish species caught in the north part of China were investigated for organophosphate residues (Bekele et al. 2021). The research showed the occurrence of total organophosphates ranging from $23.3 \mu \mathrm{g} / \mathrm{kg}$ for the muscles of the tongue sole to $107.1 \mu \mathrm{g} / \mathrm{kg}$ for the kidneys of the flathead.

The concern is that pesticides have a large spectrum of negative effects on the water ecosystem and the animals living in it. Atrazine induces complete feminization and chemical castration during sexual differentiation of the ovary in frogs (Tavera-Mendoza et al. 2002). Organochlorinated insecticides have a high affinity to fat and nerve tissue (Martyniuk et al. 2020). Long time exposure to organochlorinated pesticides harms the reproductive status of fish. Furthermore, there is a disruption of the endocrine system, immunosuppressive effects such as a decrease in the number of white blood cells, and teratogenic changes - damage to the heart and brain. DNA damage can result in cancerforming changes (De Souza et al. 2020; Hassan and Nemr 2020). Due to the high toxicity and ability of bioaccumulation, this group of pesticides is now largely banned in the world (Trang et al. 2018), but in some parts such as Africa, it is still widely used (Wolmarans et al. 2021). An important point limiting the production and use of organochlorinated pesticides was the drafting of the Stockholm Convention, which was adopted in 2009 (Stockholm Convention 2009).

Organophosphates are characterized by a high affinity for the enzyme acetylcholinesterase, which is an important regulator of nerve transfers (Chambers et al. 2010). The difference between organochlorinated pesticides and organophosphates is that organophosphates can be rapidly degraded compared to organochlorines (Cremlyn 1978). Poisoning by this group of pesticides is manifested mainly by nerve symptoms and alterations in behavior which is caused by the inhibition of this enzyme (Rao et al. 2005). Sandahl et al. (2005) determined the relationship between acetylcholinesterase activity and behaviour of juvenile rainbow trout when exposed to chlorpyrifos $(0-2.5 \mathrm{mg} / \mathrm{l})$ for $96 \mathrm{~h}$. The organophosphate inhibited tissue enzymes in a dose-dependent manner. Organophosphates also have an immunotoxic effect, which was studied in juvenile male Nile tilapia fish (Oreochromis niloticus) exposed to $3.91 \mathrm{ml} / 1$ of diazinon (Diáz-Resendiz et al. 2019).

A similar mechanism of action occurs in carbamates. Altinok et al. (2006) described the acute effect of methiocarb on juvenile rainbow trout (exposed to a concentration of $6.25 \mathrm{mg} / \mathrm{l}$ ). Pathological examination showed edemas, and exposure to carbamates can have a negative effect on fish carbohydrate metabolism and reproduction, including behavioural changes (Ghazala et al. 2014).

A significant risk for fish is posed by pyrethroid pesticides, which are more toxic to fish than to mammals. This is due to the high pyrethroid absorption ability through the gills of fish and low levels of the enzyme carboxylesterase, which is responsible for the 
hydrolysis of these compounds (Küster and Altenburger 2006). Pyrethroids affect voltage-gated sodium channels, leading to eruption of neuronal activity (Vijverberg and Van Bergkens 1990). Fish poisoning with pyrethroids is manifested by behavioral changes including lower swimming activity, neurotoxicity, oxidative stress, and reactive oxygen species formation (Goulding et al. 2013; Yang et al. 2020).

The effects of atrazine on fish were studied by Lamb et al. (2020). Male zebrafish (Danio rerio) which were exposed to atrazine showed alteration of behaviour and disruption of the endocrine system. Furthermore, there were changes in oxidative stress indicators, immunosuppression, teratogenicity, and histopathological damages (Storek and Kavlock 2010; Xing et al. 2012).

Zebrafish adults were exposed to butachlor (chloroacetanilide herbicide) at concentrations ranging from 25 to $100 \mu \mathrm{g} / \mathrm{l}$. As a result, butachlor caused endocrine disruption. In particular, the levels of thyroid hormones and sex steroids were affected and reproductive changes and immunotoxicity were reported (Chang et al. 2013).

Pesticide residues commonly found in the water ecosystem may also represent a great potential risk for human health. Various negative effects have been described after contact with these substances such as dermal irritation, immunodeficiency, teratogenicity, or risk of cancer (Thuy 2015; Basu et al. 2021). The issue of high pesticide residue concentrations in the aquatic environments is especially acute in developing countries due to the use of extremely heavy doses in intensive agricultural areas (Wesseling et al. 1997; Salameh et al. 2004). In the European Union, the maximum levels for pesticide residues (MLR) in foods and feeds of animal and plant origin are given in Regulation No 396/2005 (EC Regulation 2005). Based on the notifications listed in the RASFF portal, chlorate was the most common problem in terms of pesticide residues in fish and seafood in the whole year of 2020 (RASFF 2021). Chlorate is no longer approved as a pesticide in the EU and its MLR in fish and other aquatic organisms was set to $0.01 \mathrm{mg} / \mathrm{kg}$. Apart from the use for its herbicidal and biocidal activity, chlorate is formed as a by-product when using chlorine, chlorine dioxide or hypochlorite for the disinfection of drinking water, water for food production, and surfaces coming into contact with food.

\section{Pharmaceuticals and personal care products}

Pharmaceuticals and personal care products represent a large group of substances with different chemical properties. With the constant increase in life expectancy and improvements in the availability of health care, the consumption of both medication as well as using personal care products increases, resulting in their increasing burden on the aquatic environment. Major sources of such pollution are the discharges of the wastewater treatment plants, which are often not capable of filtering out all the chemical compounds (Rezka and Balcerzak 2016). Other dominant sources include landfills, manufactures and agriculture, swimming and sunbathing activities, use of perfumes, detergents, and others (Weng et al. 2014).

Several studies have described the occurrence of pharmaceuticals and personal care products (such as analgetics, antibiotic, musk compounds, UV filters, and others) in waters, sediments, and animals ranging from $\mathrm{ng} / \mathrm{kg}$ to $\mathrm{mg} / \mathrm{kg}$ (Vallecilos et al. 2015; Lou et al. 2016; Zhang et al. 2020). Matongo et al. (2015) found residues of antipyretics and antibiotics in the sediment from ponds. The measured values were in the range of $\mathrm{ng} / \mathrm{kg}$ to $\mathrm{mg} / \mathrm{kg}$ with the highest values of up to $0.66 \mathrm{mg} / \mathrm{kg}$ for ibuprofen and $1.25 \mathrm{mg} / \mathrm{kg}$ for metronidazole. Zhang et al. (2020) found residues of antibiotics such as norfloxacin, erythromycin, and fluoroquinolone at concentrations ranging between 1.3 and $7.9 \mu \mathrm{g} / \mathrm{kg}$ in sea sediment and up to $0.12 \mu \mathrm{g} / \mathrm{kg}$ in fish caught near the coast in South China. Battaglin et al. (2018) detected a spectrum of bioactive compounds in the water, sediment, and fish and 
frogs tissues from the Rocky Mountains National Park, USA. Described pharmaceuticals included antibiotics, stimulants, and analgetics such as ibuprofen, codeine, and others in the concentration range from $\mathrm{ng} / \mathrm{kg}$ to $\mu \mathrm{g} / \mathrm{kg}$. The concentrations of UV-filter such a homosalate, octisalate, and benzophenone- 3 were identified in the parts per trillion $\mathrm{ng} / \mathrm{l}$ in surface seawater and in $\mu \mathrm{g} / \mathrm{kg}$ in sediment and corals from Hawaii. Lou et al. (2016) detected seven kinds of synthetic musks in sediment samples of the Yellow River Delta wetland, including celestolide, phantolide, traseolide, galaxolide, tonalide, musk xylene, and musk ketone at concentrations of up to $8.6 \mu \mathrm{g} / \mathrm{kg}$. Liu et al. (2018) found residues of 19 types of antibiotics in wild marine fish tissues from Laizhou Bay (China) at concentrations of up to $500 \mu \mathrm{g} / \mathrm{kg}$. Vallecilos et al. (2015) determined the presence of galaxolide and tonalide at concentrations of $18.04 \mu \mathrm{g} / \mathrm{kg}$ and $8.42 \mu \mathrm{g} / \mathrm{kg}$, respectively in fish samples from the Ebro River.

Pharmaceuticals are compounds designed to have therapeutical effects even at low concentrations. It means the residues of such substances might have negative effects on non-target organisms such as fish ( $\mathrm{Ji}$ et al. 2013; Pieróg et al. 2021). Various analgesics have been proven to cause genotoxicity (Guiloski et al. 2017), changes in oxidative stress (e.g. study on Daphnia Magna by Gómez-Oliván et al. [2014]), hormone disruptions in frogs (Efosa et al. 2017), organ damage, endocrinological disruption, and reproductive problems such as lower production of eggs and hatching success in fish ( $\mathrm{Ji}$ et al. 2013). Antibiotics cause a reduction in growth, increased risk of bacteria resistance, and fish embryo genotoxicity (Chowdhury et al. 2020; Jo et al. 2021). Similarly, anti-cancer drugs such as cyclophosphamide have been proven to have a genotoxicity effect. Novak et al. (2017) described the genotoxic effect of the anti-cancer drug on zebrafish liver. Antidiabetics such as metformin at environmentally relevant concentrations can cause endocrinological disruption in fathead minnows with induced significant up-regulation of vitellogenin in male fish ( $\mathrm{Niemuth}$ et al. 2015). Anticonvulsants cause behavioral changes and development delays (Pieróg et al. 2021). Xie et al. (2016) described the effect of antihistamines on fish with behavioral changes - swimming activity, growth, and feeding rate in fish. Psychiatric drugs such as sertraline, fluoxetine, citalopram and others cause behavioural changes - feeding, boldness, activity, sociality, endocrine disruption, changes in biochemical and oxidative stress indices, and embryotoxicity (Pohl 2019; Byeon et al. 2020; Vaclavik et al. 2020). Cahova et al. (2021) studied the influence of the UV filter ethylhexyl methoxycinnamate on juvenile rainbow trout. The results showed that UV filters caused oxidative stress, distribution of saccharide, lipid and protein metabolism, and extensive damage of hepatic parenchyma. Acute toxicity of musk ambrette (nitro musk) on zebrafish embryos was observed by Qu et al. (2018). The embryos showed developmental delays, pericardial oedema, circulatory disturbances, and curved body axis. Carlsson et al. (2000) observed the impact of musk ketone on reproduction in zebrafish. Histopathological changes and a weight reduction of gonads were typical for fish exposed to $33 \mu \mathrm{g} / 1$ of this xenobiotic.

\section{Nanoparticles, nanofibres and microplastics}

The basic definition states that nanoparticles are particles of a size between 1 and $100 \mathrm{~nm}$ (ISO 2011). The most often used and described synthetic nanoparticles are composed of metals, metal oxides, and carbon-containing compounds (Li et al. 2020; Čaloudova et al. 2021).

Various studies have demonstrated the occurrence of these substances in water ecosystems. Tou et al. (2021) detected the presence of nanoparticles from estuarine sediments of the Yangtze River (Shanghai). The measured values of substances were up to $9.61 \times 10^{7} \mathrm{parts} / \mathrm{mg}$ $(\mathrm{Zn})$ and up to $1.21 \times 10^{7}$ parts/mg (Ti). Yin et al. (2017) conducted a survey on $\mathrm{TiO}_{2}$ 
particles in seafood and surimi products in China. The results showed the occurrence of the particles in the range of 6-12 $\mathrm{mg} / \mathrm{kg}$ in seafood products and $2-81 \mathrm{mg} / \mathrm{kg}$ in surimi.

The nanoparticle size, a large surface area, and the ability to produce reactive oxygen species play a critical role in the toxicity of these substances ( $\mathrm{Nel}$ et al. 2006). Georgantzopoulou et al. (2020) described an increasing risk of mortality and development delay of the copepod nauplii (Tisbe battagliai) after exposure to $\mathrm{Ag}$ and $\mathrm{TiO}_{2}$ nanoparticles. The effect of nanoparticles of metal oxides (aluminum, copper, and titanium) on the liver antioxidant system of the Nile fish (Oreochromis niloticus) was studied by Canli and Canli (2020). Results of the oxidative stress showed traces indicating a metabolic load on the liver (mainly catalase and superoxide dismutase). The same results and signs of lipid peroxidation were shown in the research by Oya-Silva et al. (2021) on Rhamdia quelen. Miranda et al. (2016) observed many alterations in the liver tissue (necrosis, vascular congestion, leukocyte infiltration) of juvenile fish Prochilodus lineatus after exposure to $10 \mu \mathrm{g} / 1 \mathrm{TiO}_{2}$. A study by Cong et al. (2017) demonstrated the embryonic toxicity effect of zinc nanoparticles to marine medaka (Oryzias melastigma). After the exposure, a reduced hatching success and increasing malformation rate of the hatched larvae were described. Other negative effects after $\mathrm{Zn}^{2+}$ particles exposure include DNA damage and neurotoxicity (Chen et al. 2020; Li et al. 2020), gill pathologies such as oedema and thickening of the lamellae (Federici et al. 2007).

Microplastics are defined as a heterogeneous mixture of differently shaped materials referred to as fragments, fibres, spheroids, granules, pellets, flakes, or beads, in the range of 0.1-5000 $\mu \mathrm{m}$ (NOAA 2014; EFSA 2016; Hollerova et al. 2021). The occurrence of various microplastic types such as polyethylene, polypropylene, polystyrene, polyethylene terephthalate has been described in the aquatic environment (Ferreira et al. 2020; Ghosh et al. 2021; Yu et al. 2021). After entering the environment, microplastics are gradually stored in the water, sediment, and water organisms. Ferreira et al. (2020) demonstrated the presence of microplastic concentrations from the surface water, sediment and fish from a coastal area in the Fiji-Pacific region. The most identified types of microplastics include polyethylene, latex, and polypropylene. Ghosh et al. (2021) observed the presence of microplastic in commercial marine fish from Bangladesh. The results showed the occurrence of 215 types of microplastic from GIT samples with average abundance in the range of 1.0-3.8 items per species. Zhang et al. (2021) measured microplastics from water, sediments, and fish samples in China with an average abundance of 2.5 particles/1 (water), 0.04 particles/g (sediment) and 0.92 particles/individual (crayfish tissues).

The presence of microplastics in organisms poses many negative health risks. Endocrine disruption, a decreased growth, lower survival probability, changes in the intestinal structure, lower weight, liver toxicity, reproductive problems in fish have been described as a result of microplastic action (Rochman et al. 2014; Peda et al. 2016; Naidoo and Glass om 2019).

In addition to the mechanical effect of plastic materials per se, polymeric additives which are commonly added to plastic materials to improve their functions, also pose a considerable risk of toxic effects. Usual groups of microparticle modifiers include plasticizers, flame retardants, impact modifiers, antioxidants, antimicrobials, and UV stabilizers (Marturano et al. 2017).

\section{Conclusion}

The review described several groups of substances formed by human activity, which have the potential for pollution and storage in the aquatic environment and a subsequent transfer to the aquatic food chain. Based on the knowledge reported in scientific studies and the RASFF portal, the aquatic contaminants have the potential to affect not only the welfare 
and health of aquatic animals but also, mostly in the case of heavy metals, the safety of food products they are turned into. For this reason, it is necessary to constantly monitor the pollution in different parts of the aquatic environment (from the source of possible pollution to living organisms serving as a source of human food) and to try to limit their occurrence as much as possible. Further studies concerning the effects of sediment pollution on aquatic biota are necessary in order to reveal toxic effects of pollutant mixtures and their mixed toxicity on aquatic biota.

\section{Acknowledgement}

This work was supported by project IGA VETUNI 208/2020/FVHE.

\section{References:}

Abd-Elghany SM, Zaher HA, Elgazzar MM, Sallam KI 2020: Effect of boiling and grilling on some heavy metal residues in crabs and shrimps from the Mediterranean Coast at Damietta region with their probabilistic health risk assessment. J Food Compost Anal 93: 103606

Altinok I, Capkin E, Karahan S, Boran M 2006: Effects of water quality and fish size on toxicity of methiocarb, a carbamate pesticide, to rainbow trout. Environ Toxicol Pharmacol 22: 20-26

Arisekar U, Shakila R, Jeyasekaran G, Shalini R, Kumar P, Malani AH, Rani V 2019: Accumulation of organochlorine and pyrethroid pesticide residues in fish, water, and sediments in the Thamirabarani river system of southern peninsular India. Environ Nanotechnol Monit Manag 11: 100194

Azizi G, Layachi M, Akodad M, Yanez-Ruiz DR, Martin-García AI, Baghour M, Mesfioui A, Skalli A, Moumen A 2018: Seasonal variations of heavy metals content in mussels (Mytilus galloprovincialis) from Cala Iris offshore (Northern Morocco). Mar Pollut Bull 137: 688-694

Basu S, Chanda A, Gogoi P, Bhattacharyya S 2021: Organochlorine pesticides and heavy metals in the zooplankton, fishes, and shrimps of tropical shallow tidal creeks and the associated human health risk. Mar Pollut Bull 165: 112170

Battaglin WA, Bradley PM, Iwanowicz I, Journey CA, Walsch HLS, Blazer, VS 2018: Pharmaceuticals, hormones, pesticides, and other bioactive contaminants in water, sediment, and tissue from Rocky Mountain National Park, 2012-2013. Sci Total Environ 643: 651-673

Beck K, Mariani, M, Fletscher MS, Schneider L, Aqiuano-Lopez MA, Gadd PS, Hejnis H, Saunders KM, Zawadski A 2020: The impacts of intensive mining on terrestrial and aquatic ecosystems: A case of sediment pollution and calcium decline in cool temperate Tasmania, Australia. Environ Pollut 265: 114695

Bekele TG, Zhao H, Wang Q 2021: Tissue distribution and bioaccumulation of organophosphate esters in wild marine fish from Laizhou Bay, North China: Implications of human exposure via fish consumption. J Hazard Mater 401: 123410

Bischoff K, Priest H, Mount-Long A 2010: Animals as sentinels for human lead exposure: A case report. J Med Toxicol 6: 185-189

Briffa J, Sinagra E, Blundell R 2020: Heavy metal pollution in the environment and their toxicological effects on humans. Heliyon 6: 04691

Buah-Kwofie A, Humphries MS 2021: Organochlorine pesticide accumulation in fish and catchment sediments of Lake St Lucia: Risks for Africa's largest estuary. Chemosphere 274: 129712

Buck DG, Evers DC, Adams E, Digangi J, Beeler B, Samanek J, Petrklic J, Turnquist MA, Speranskaya O, Regan K, Johnson S 2019: A global-scale assessment of fish mercury concentrations and the identification of biological hotspots. Sci Total Environ 687: 956-966

Burger J 2008: Assesment and management of risk to wild from cadmium. Sci Total Environ 389: 37-45

Byeon E, Park JC, Hagiwara A, Han J, Lee JS 2020: Two antidepressants fluoxetine and sertraline cause growth retardation and oxidative stress in the marine rotifer Brachionus koreanus. Aquat Toxicol 218: 105337

Cahova J, Blahova J, Marsalek P, Doubkova V, Franc A, Gajarova M, Tichy F, Mares J, Svobodova Z 2021: The biological activity of the organic UV filter ethylhexyl methoxycinnamate in rainbow trout (Oncorhynchus mykiss). Sci Total Environ 774: 145570

Čaloudová H, Čaloudová J, Svobodová Z 2021: A review of the effects of metallic nanoparticles on fish. Acta Vet Brno 90: 331-347

Canli EG, Canli M 2020: Effects of aluminum, copper and titanium nanoparticles on the liver antioxidant enzymes of the Nile fish (Oreochromis niloticus). Energy Rep 6: 62-67

Carlsson G, Örn S, Andersson PL, Söderström H, Norrgren L 2000: The impact of musk ketone on reproduction in zebrafish (Danio rerio). Mar Environ Res 50: 1-5

Castro-Gonzalez MI, Mendez-Armenta M 2008: Heavy metals: Implications associated to fish consumption. Environ Toxicol Pharmacol 26: 263-271

Chambers HW, Meek EC, Chambers JE 2010: Chemistry of organophosphorus insekticides. In: Kriger, R., (Ed). Hayes handbook of pesticides toxicology 2: 1395-1398 
Chang J, Liu S, Zhou S, Wang M, Zhu G 2013: Effects of butachlor on reproduction and hormone levels in adult zebrafish (Danio rerio). Exp Toxicol Pathol 65: 205-209

Chen F, Wu L, Xiao X, Rong L, Li M, Zou X 2020: Mixture toxicity of zinc oxide nanoparticle and chemicals with different mode of action upon Vibrio fischeri. Environ Sci Eur 32: 1-10

Chowdhury J, Mandal TK, Mondal, S 2020: Genotoxic impact of emerging contaminant amoxicillin residue on zebra fish (Danio rerio) embryos. Heliyon: e05379

Cong Y, Jing F, Wang J, Mu J 2017: The embryotoxicity of ZnO nanoparticles to marine medaka, Oryzias melastigma. Aquat Toxicol 185: 11-18

Costa F, Coelho JP, Baptista J, Martinho F, Pereira ME, Pardal MA 2020: Mercury accumulation in fish species along the Portuguese coast: Are there potential risks to human health? Mar Pollut Bull 150: 110740

Commission Regulation (EC) No 1881/2006 of 19 December 2006 setting maximum levels for certain contaminants in foodstuffs. Off J Euro Union L 364: 5-24

Cremlyn RJW 1978: Pesticides: Preparation and mode of action. Wiley, Chichester, Uk, 240.

Dabeka RW, Mckenzie AD, Forsyth DS 2011: Levels of total mercury in predatory fish sold in Canada in 2005. Food Addit Contam Part A Chem. Anal Control Expo Risk Assess 28: 740-743

De Souza RM, Seibert D, Quesada HB, Basseti F, Fagundes-Klen MR 2020: Occurrence, impacts and general aspects of pesticides in surface water: A review. Process Saf Environ Prot 135: 22-37

Díaz-Resendiz KJG, Ortiz-Lazareno PC, Covantes-Rosales CE, Trujillo-Lepe AM, Toledo-Ibarra GA, VenturaRamón GH, Girón-Peréz MI 2019: Effect of diazinon, an organophosphate pesticide, on signal transduction and death induction in mononuclear cells of Nile tilapia fish (Oreochromis niloticus). Fish Shellfish Immunol 89: 12-17

Dvidedi AK 2017: Rerearches in water pollutation: A Review. IRJNAS, 118-142

EC Regulation. No 396/2005 of the European Parliament and of the Council of 23 February 2005 on maximum residue levels of pesticides in or on food and feed of plant and animal origin and amending Council Directive 91/414/EEC 2005

Efosa NJ, Kleiner W, Werner K, Hoffmann F 2017: Diclofenac can exhibit estrogenic modes of action in male Xenopus laevis, and affects the hypothalamus-pituitary-gonad axis and mating vocalizations. Chemosphere 173: 69-77

Ejaz N, Akhtar N, Nisar H, Naeem UA 2010: Environmental impacts of improper solid waste management in developing countries: a case study of Rawalpindi City. Sustain world 142: 379-387

European Food Safety Authority (EFSA) 2005: Opinion of the scientific panel on contaminants in the food chain and on a request from the European Parliament related to the safety assessment of wild and farmed fish. The EFSA 236: 1-118

European Food Safety Authority (EFSA) 2016: Presence of microplastics and nanoplastics in food, with particular focus on seafood. The EFSA, 30

Federici G, Shaw BJ, Handy RD 2007: Toxicity of titanium dioxide nanoparticles to rainbow trout (Oncorhynchus mykiss): Gill injury, oxidative stress, and other physiological effects. Aquat Toxicol 84: 415-430

Ferreira M, Thompson J, Paris A, Rohindra D, Rico C 2020: Presence of microplastics in water, sediments and fish species in an urban coastal environment of Fiji, a Pacific small island developing state. Mar Pollut Bull 153: 110991

Georgantzopoulou A, Farkas J, Ndungu K, Coutris C, Carvalho PA, Booth AM, Makcen A 2020: Wastewateraged silver nanoparticles in single and combined exposures with titanium dioxide affect the early development of the marine Copepod Tisbe battagliai. Environ Sci Technol 54: 12316-12325

Ghazala SM, Al-Ghanim KA, Sultana S, Al-Balawi HFA, Sultana A, Al-Misned F, Ahmed Z 2014: Acute toxicity II: Effect of organophosphates and carbamates to Catla Catla fingerling. J Anim Plant Sci 24: 1795-1801

Ghosh GC, Akter SM, Islam RM, Habib A, Chakraborty TK, Zaman S, Kabir EAHM, Shipin OV, Wahid MA 2021: Microplastics contamination in commercial marine fish from the Bay of Bengal. Reg Stud Mar Sci 44: 101728

Gómez-Oliván L, Martinéz M, García Medina S, Valdéz-Alanís A, Islas-Flores H, Neri N 2014: Genotoxic response and oxidative stress induced by diclofenac, ibuprofen and naproxen in Daphnia magna. Drug Chem Toxicol 351: 391-399

Goulding AT, Shelley LK, Peter S, Kennedy CHJ 2013: Reduction in swimming performance in juvenile rainbow trout (Oncorhynchus mykiss) following sublethal exposure to pyrethroid insecticides. CBCC 157: 280-286

Guiloski IC, Ribas JLC, Piancini LDS, Dagostim AC, Cirio SM, Fávaro LF, Boschen SL, Cestari MM, Da Cunha C, Silva de Assis HC 2017: Paracetamol causes endocrine disruption and hepatotoxicity in male fish Rhamdia quelen after subchronic exposure. Environ Toxicol Pharmacol 53: 111-120

Hassaan, MA, Nemr AE 2020: Pesticides pollution: Classifications, human health impact, extraction and treatment techniques. Egypt J Aquat Res 46: 207-220

Haseena M, Malik MF, Javed A, Arshad S, Asif N, Zulfiqar S, Hanif J 2017: Water pollution and human health, ISO4 Standard. Environ Risk Assess Remediat 1: 16-19

Hollerova A, Hodkovicova N, Blahova J, Faldyna M, Marsalek P, Svobodova Z 2021: Microplastics as a potencial risk for aquatic environment organisms - a review. Acta Vet Brno 90: 99-107

Hontela A, Daniel C, Ricar AC 1996: Effects of acute and subacute exposures to cadmium on the interrenal and thyroid function in rainbow trout, Oncorhynchus mykiss. Aquat Toxicol 35: 171-182 
Huang W, Cao L, Liu J, Lin L, Dou S 2010: Short-term mercury exposure affecting the development and antioxidant biomarkers of Japanese flounder embryos and larvae. Ecotoxicol Environ Saf 73: 1875-1883

International Organization for Standardization 2011: Nanotechnologies-Vocabulary-Part 4: Nanostructured materials. International (ISO Standard 80004-4). ISO copyright office, Geneva, 7

Ji K, Liu X, Lee S, Kang S, Kho Y, Giesy JP, Choi K 2013. Effects of non-steroidal anti-inflammatory drugs on hormones and genes of the hypothalamic-pituitary-gonad axis, and reproduction of zebrafish. J Hazard Mater 254-255: 242-251

Jo H, Raza S, Farooq A, Kim J, Unno T 2021: Fish farm effluents as a source of antibiotic resistance gene dissemination on Jeju Island. South Korea Environ Pollut 276: 116764

Küster E, Altenburger R 2006: Comparison of cholin- and carboxylesterase enzyme inhibition and visible effects in the zebra fish embryo bioassay under short-term paraoxon-methyl exposure. Biomarkers 11: $341-354$

Lamb SD, Chia JHZ, Johnson SL 2020: Paternal exposure to a common herbicide alters the behavior and serotonergic system of zebrafish offspring. PLoS One 15: e0228357

Li H, Jiang W, Pan Y, Li F, Wang Ch, Tian H 2021: Occurrence and partition of organochlorine pesticides (OCPs) in water, sediment, and organisms from the eastern sea area of Shandong Peninsula, Yellow Sea, China. Mar Pollut Bull 162: 111906

Li M, Liu W, Slaveykova VI 2020: Effects of mixtures of engineered nanoparticles and metallic pollutants on aquatic organisms. Environments 7: 1-20

Liu S, Bekele TG, Zhao H, Cai X, Chen J 2018: Bioaccumulation and tissue distribution of antibiotics in wild marine fish from Laizhou Bay, North China. Sci Total Environ 631: 1398-1405

Lou YH, Wang J, Wang L 2016: Determination of synthetic musks in sediments of Yellow river Delta Wetland, China. Bull Environ Contam Toxicol 97: 78-83

Marturano V, Cerruti P, Ambrogi V 2017: Polymer additives. Phys Sci Res: 1-20

Martyniuk CHJ, Mehinto AC, Dendslow ND 2020: Organochlorine pesticides: Agrochemicals with potent endocrine-disrupting properties in fish. Mol Cell Endocrinol 507: 110764

Matongo S, Birungi G, Moodley B, Ndungu P 2015: Pharmaceutical residues in water and sediment of Msunduzi River, Kwazulu-Natal, South Africa. Chemosphere 134: 133-140

Meyer W, Kretschmer M, Hoffmann A, Harisch G 1991: Biochemical and histochemical observations on effects of low-level heavy metal load (lead, cadmium) in different organ systems of the freshwater crayfish, Astacus astacus L. (crustacea: Decapoda). Ecotoxicol Environ Saf 21: 137-156

Miranda RR, Damaso Da Silveira AL, De Jesus IP, Grotzer SR, Voigt CL, Campos SX, Garcia, JR, Randi, MA, Ribeiro CA, Filipak NF 2016: Effects of realistic concentrations of $\mathrm{TiO}_{2}$ and $\mathrm{ZnO}$ nanoparticles in Prochilodus lineatus juvenile fish. Environ Sci Pollut Res Int 23: 5179-5188

Mwevura H, Kylin H, Vogt T, Bouwman H 2021: Dynamics of organochlorine and organophosphate pesticide residues in soil, water, and sediment from the Rufiji River Delta, Tanzania. Reg Stud Mar Sci 41: 101607

Naidoo T, Glassom D 2019. Decreased growth and survival in small juvenile fish, after chronic exposure to environmentally relevant concentrations of microplastic. Mar Pollut Bull 145: 254- 259

National Oceanic and Atmospheric Administration NOAA, 2014. http:/www.deq.state.va.us/programs/ coastalzonemanagment.aspx.

Nel A, Xia TL, Madler L, Li N 2006: Toxic potential of materials at the nanolevel. Science 311: 622-627

Niane B, Guderon S, Feder F, Legros S, Malick Ngom P, Moritz R 2019: Impact of recent artisanal small-scale gold mining in Senegal: Mercury and methylmercury contamination of terrestrial and aquatic ecosystems. Sci Total Environ 669: 185-193

Nicklisch, SCT, Bonito LT, Sandin S, Hamdoun A 2017: Mercury levels of yellowfin tuna (Thunnus albacares) are associated with capture location. Environ Pollut 229: 87-93

Niemuth NJ, Jordan R, Crago J, Blanksma C, Johnson R, Klaper RD 2015: Metformin exposure at environmentally relevant concentrations causes potential endocrine disruption in adult male fish. Environ Toxicol Chem 34: 291-296

Novak M, Žegura B, Modic B, Heath E, Filipič M 2017: Cytotoxicity and genotoxicity of anticancer drug residues and their mixtures in experimental model with zebrafish liver cells. Sci Total Environ 601-602: 293-300

Owa FD 2013: Water: sources, effects, control and management. Mediterr J Soc Sci 4: 64-68

Oya-Silva LF, Vicari T, Rodrigo Disner G, Lirola JR, Klingelfus T, Goncalves HDLS, Leite TPB, Calado SLDM, Voigt CL, Silva De Assis HC, Cestari MM 2021: Tissue-specific genotoxicity and antioxidant imbalance of titanium dioxide nanoparticles $\left(\mathrm{NPTiO}^{2}\right)$ and inorganic lead $(\mathrm{PbII})$ in a neotropical fish species. Environ Toxicol Pharmacol 82: 103551

Peda C, Caccamo L, Fossi MC, Gai F, Andaloro F, Genovese L, Perdichizzi A, Romeo T, Marichiollo G 2016: Intestinal alterations in European sea bass Dicentrarchus labrax (Linnaeus, 1758) exposed to microplastics: Preliminary results. Environ Pollut 212: 251-256

Pieróg M, Socała K, Doboszewska U, Wyska E, Guz L, Szopa A, Serefko A, Polezsak E, Wlaź P 2021: Effects of classic antiseizure drugs on seizure activity and anxiety-like behavior in adult zebrafish. Toxicol App Pharmacol 415: 115429

Pohl J 2019: Zebrafish (Danio rerio) embryo-larvae locomotor activity data analysis: Evaluating anxiolytic effects of the antidepressant compound citalopram. Data in Brief 27: 104812

Qu L, Zhao C, Wang C 2018: A Nnovel zebrafish (Danio rerio) assay for assessing musk ambrette-induced toxicity. Bull Environ Contam Toxicol 101: 80-85 
Rao JV, Begum G, Pallela R, Usman PK, Rao RN 2005: Changes in behaviour and brain acetylcholinesterase activity in mosquito fish, Gambusia affinis in response to the sub-lethal exposure to chlorpyrifos. Int J Environ Res Public Health 2: 474-483

RASFF 2021: Available at: https://webgate.ec.europa.eu/rasff-window/screen/list

Regulation (EU) 2017/852 of European Parliament and of the council of 17 May 2017 on mercury and repealing Regulation (EC) No 1102/2008. Official Journal of the European Union.

Reis J, Mizusawa H 2019: Environmental challenges for the nervous system and brain in Japan. Rev Neurol 175: 693-697

Rezka P, Balcerzak W 2016: Occurrence of antidepressants - from wastewater to drinking water. Technic Trans 1: $145-155$

Rochman CHM, Kurobe T, Flores I, Swee JT 2014: Early warning signs of endocrine disruption in adult fish from the ingestion of polyethylene with and without sorbed chemical pollutants from the marine environment. Sci Tot Environ 493: 656-661

Rogers JT, Richards JG, Wood CM 2003: Ionoregulatory disruptionas the acute toxic mechanism for lead in the rainbow trout (Oncorhynchus mykkis). Aquat Toxicol 64: 215-234

Salameh PR, Baldi I, Brochard P, Bernadette AS 2004: Pesticides in Lebanon: a knowledge, attitude, and practice study. Environ Res 94: 1-6

Sandahl JF, Baldwin DH, Jekins JJ, Scholz NL 2005: Comparative thresholds for acetylcholinesterase inhibition and behavioral impairment in coho salmon exposed to chlorpyrifos. Environ Toxicol Chem 24: 136-145

Serafim A, Bebianno M 2007: Kinetic model of cadmium accumulation and ellimination and metallothione response in Ruditapes decussatus. Environ Toxicol Chem 26: $960-969$

Shi Z, Wang X, Shi Y, Ni S, Li Y, Wang D, Wang R 2019: Impact of intensive mining on the distribution of heavy metals in water and sediment of Anning River, southwest China, geochemistry: exploration. Environ Anal 19: 24-30

Skenderovic I, Kalac B, Becirovic S 2015: Environmental pollution and waste management. Balkan J Health Sci 3: $2-10$

Sorensen EMB, Ramirezmitchell R, Pradzynski A, Bayer TL, Wenz LL 1985: Stereological analyses of hepatocyte changes parallel arsenic accumulation in the livers of green sunfish, J Environ Pathol Toxicol Oncol 7: $195-210$

Stockholm Convention 2009, COP4 final, Earth Negotiation Bulletin 15: 174

Storek ET, Kavlock R 2010: Pesticides as endocrinine-disrupting chemicals, In: Kriger, R., (Ed.) Hayes handbook of pesticides toxicology. Elseiver, Amsterdam, the Netherlands 23: 551- 569

Tavera - Mendoza L, Ruby S, Brousseau P, Fournier M, Cyr D, Marcogliese D 2002: Response of the amphibian tadpole Xenopus laevis to atrazine during sexual differentiation of the ovary. Environ Toxicol Chem 21: 1264-1270

Thuy TT 2015: Effects of DDT on environment and human health. J Soc Dev Sci 2: 108-114.

Tou F, Wu J, Fu J, Niu Z, Liu M, Yang Y 2021: Titanium and zinc-containing nanoparticles in estuarine sediments: Occurrence and their environmental implications. Sci Tot Environ 754: 142388

Trang CTT, Thung DC, Kha PT, Nam LV, Nghi DT 2018: Residue of organochlorinated pesticides, (OCPs) in some organisms of the tidal flats in the northern part of Vietnam. J Mar Sci Technol 19: 427-433

Ungherese G, Mengoni A, Somigli S, Baroni D, Focardi S, Ugolini A 2010: Relationship between heavy metals pollution and genetic diversity in Mediterranean populations of the sandhopper Talitrus saltator (Montagu) (Crustacea, Amphipoda). Environ Poll 158: 1638-1643

Usman UL, Muhammad AZ, Banerjee S, Neksumi M 2021: Bioaccumulation potential of heavy metals in some commercially fish species from Cika Koshi reservoir Katsina North- western Nigeria: Threat to ecosystem and public health. Materials Today: Proceedings, 2214-7853

Vaclavik J, Sehonova P, Hodkovicova N, Vecerkova L, Blahova J, Franc A, Marsalek P, Mares J, Tichy F, Svobodova Z, Faggio C 2020: The effect of foodborne sertraline on rainbow trout (Oncorhynchus mykiss). Sci Total Environ 708: 135082

Vallecillos L, Pocorull E, Borrul F 2015: Influence of pre-treatment process on matrix effect for the determination of musk fragrances in fish and mussel. Talanta 134: 690-698

Vijverberg HPM, Van Bergkens J 1990: Neurotoxicological effects and the mode of action of pyrethroid insecticides. Crit Rev Toxicol 21: 105-126

Wei J, Duan M, Li Y, Nwankwegu AS, Ji Y, Zhang J 2019: Concentration and pollution assessment of heavy metals within surface sediments of the Raohe Basin, China. Sci Rep 9: 13100

Weng SC, Sun PZ, Huang WW, Lee CH, Blatchley LT 2014: The presence of pharmaceuticals and personal care products in swimming pools. Environ Sci Technol Lett 1: 495-498

Wesseling C, Mcconnell R, Partanen T, Hogstedt C 1997: Agricultural pesticide use in developing countries: health effectsand research needs. Int J Health Survey 27: 273-308

Wolmarans NJ, Bervoets L, Gerber R, Yohanees YB, Shouta MM, Ikenawa NY, Ishizuka M, Meire P, Smith PJ, Wepener V 2021: Bioaccumulation of DDT and other organochlorine pesticides in amphibians from two conservation areas within malaria risk regions of South Africa. Chemosphere 274: 129956

Xie D, CHen Q, Gong S, An J, Li Y, Lian X, Liu Z, Shen Y, Giesy JP 2020: Exposure of zebrafish to environmentally relevant concentrations of mercury during early life stages impairs subsequent reproduction in adults but can be recovered in offspring. Aquat Toxicol 229: 105655 
Xie Z, Lu G, Hou K, Qin D, Yan Z, Chen W 2016: Bioconcentration, metabolism and effects of diphenhydramine on behavioral and biochemical markers in crucian carp (Carassius auratus). Sci Total Environ 544: 400-409

Xing HJ, Li S, Wang ZL, Gao XJ, Xu SW, Wang XL 2012: Histopathological changes and antioxidant response in brain and kidney of common carp exposed to atrazine and chlorpyrifos. Chemosphere 88: $377-383$

Yang CH, Lim W, Song G 2020: Mediation of oxidative stress toxicity induced by pyrethroid pesticides in fish. Comp Biochem 234: 108758

Yin CH, Zhao W, Liu R, Liu R, Wang Z, Zhu L, Chen W, Liu S 2017: $\mathrm{TiO}^{2}$ particles in seafood and surimi products: Attention should be paid to their exposure and uptake through foods. Chemosphere 188: 541-547

Yu H, Peng J, Cao X, Wang Y, Zhang Z, Xu Y, Qi W 2021: Effects of microplastics and glyphosate on growth rate, morphological plasticity, photosynthesis, and oxidative stress in the aquatic species Salvinia cucullata. Environ Pollut 279: 116900

Zeng L, Luo G, He T, Yanna Guo Y, Qian X 2016: Effects of sulfate-reducing bacteria on methylmercury at the sediment-water interface. J Environ Sci 46: 214-219

Zhang R, Yu K, Li A, Wang Y, Pan CH, Huang X 2020: Antibiotics in coral reef fishes from the South China Sea: Occurrence, distribution, bioaccumulation, and dietary exposure risk to human. Sci Total Environ 704: 135288

Zhang D, Fraser MA, Huang W, Ge CH, Wang Y, Zhang CH, Guo P 2021: Microplastic pollution in water, sediment, and specific tissues of crayfish (Procambarus clarkii) within two different breeding modes in Jianli, Hubei province, China. Environ Pollut 272: 115939

Zhu H, Zheng M, Zheng L, Wang L, Lou Y, Zhao Q, Zhang Y 2019: Distribution and ecotoxicological effects of polyhalogenated carbazoles in sediments from Jiaozhou Bay wetland. Mar Pollut Bull 146: 393-398 